\title{
Penerepan Model Pembelajaran Predict Observe, Discuss, Explain (PODE) untuk Meningkatkan Keterampilan Proses Sains Siswa Kelas V SD Inpres Unggulan BTN Pemda Kota Makassar
}

\author{
Muhammad Irfan ${ }^{1}$, Syahrani ${ }^{2}$ \\ ${ }^{1}$ Program Studi PGSD Fakultas Ilmu Pendidikan Universitas Negeri Makassar \\ ${ }^{2}$ SD Inpres Unggulan BTN Pemda, Makassar, Sulawesi Selatan \\ ${ }^{1}$ m.irfan@unm.ac.id \\ ${ }^{2}$ syahraniirfan@gmail.com
}

\begin{abstract}
ABSTRAK
Penelitian ini bertujuan untuk mengetahui bagaimanakah gambaran kemampuan keterampilan proses sains siswa kelas V SD Inp. Unggulan BTN PEMDA melalui penerapan Model Pembelajaran Predict Observe, Discuss, Explain (PODE), Penelitian ini didesain dalam bentuk deskriptif guna menjelasakan dengan tepat seperti apa keterampilan proses sains siswa kelas V SD Inp. BTN PEMDA Kota Makassar. Penggunaan metode deskriptif bertujuan untuk mendapatkan gambaran mengenai keterampilan proses sains siswa kelas V SD Inp. Unggulan BTN PEMDA secara mendalam, terperinci dan utuh. Jenis data yang diambil adalah jenis data kuantitatif deskriptif, dimana data diambil dari pengamatan langsung oleh peneliti terkait keterampilan proses sains siswa kelas V SD Inp. Unggulan BTN PEMDA. Hasil penelitian adalah: 1) kemampuan melakukan observasi dikategorikan baik; 2) kemampuan melakukan prediksi/hipotesis dikategorikan baik; 3) kemampuan anak melakukan percobaan dikategorikan baik; 4) kemampuan menarik kesimpulan dan melaporkan hasil pengamatan dikategorikan cukup. Secara keseluruhan keterampilan proses siswa dapat dikategorikan baik walaupun masih ada bebarapa aspek yang perlu untuk ditingkatkan
\end{abstract}

Kata Kunci: Keterampilan Proses sains, Predict Observe, Disscus, Explain (PODE), Pembelajaran IPA.

\section{PENDAHULUAN}

Model pembelajaran Predict-ObserveDiscuss, Explain (PODE) merupakan pengembangan model pembelajaran berdasarkan model pembelajaran yang pertama kali diperkenalkan oleh White dan Gunstone (dalam Keeratichamroen, 2007) yaitu model pembelajaran Predict-Observe-Explain (POE). Model ini bertujuan mengeksplorasi pengetahuan awal siswa dan memberikan kesempatan kepada setiap siswa untuk berperan secara aktif dalam proses belajar.

Sintaks pada model ini adalah predict, observe, discuss dan explain. Langkah-langkah keempat kegiatan tersebut dalam penerapan model PODE yaitu:

1. Predict: pada tahap ini, meminta peserta didik untuk mengamati apa yang akan didemonstrasikan, kemudian berhipotesis (membuat prediksi) terhadap fenomena yang mereka amati/rasakan.

2. Observe: pada tahap ini, siswa melakukan percobaan atau guru menunjukkan proses atau demonstrasi dan meminta peserta didik untuk mencatat apa yang terjadi.
3. Discuss: pada tahap ini, siswa mendiskusikan fakta-fakta yang telah mereka amati dalam percobaan yang dilakukan.

4. Explain: pada tahap ini, guru meminta peserta didik untuk memberikan penjelasan sekaitan hasil pengamatan yang dilakukan mengenai mengapa terjadi hal tersebut serta menjelaskan perbedaan antara prediksi yang dibuatnya dengan hasil observasinya (Irfan dan Syamsuardi, 2017)

Model pembelajaran PODE mengacu pada filsafat konstruktivis, di mana siswa akan membangun pengetahuan di pikiranya sendiri berdasarkan pengalaman langsung yang ditemuinya pada saat pembelajaran. Selama pembelajaran dengan model ini, siswa didukung untuk membangun pengetahuan mereka sendiri melalui proses penyelidikan. Siswa bekerja dengan peralatan sederhana pada setiap pengamatan mereka baik dalam demonstrasi maupun eksperimen. Model PODE merupakan suatu model yang efisien untuk menciptakan kegiatan eksplorasi bagi 
para siswa mengenai konsep ilmu pengetahuan. Model pembelajaran ini melibatkan siswa dalam meramalkan suatu fenomena, melakukan observasi melalui demonstrasi, melakukan diskusi dalam rangka meningkatkan keterampilan sosial siswa dan akhirnya menjelaskan hasil demonstrasi dan ramalan mereka sebelumnya. Terdapat beberapa alasan dalam pembelajaran mengapa digunakan model pembelajaran PODE tersebut antara lain: (1) siswa merasa senang untuk melaksanakannya, hal ini disebabkan dalam kegiatan belajar siswa tidak hanya terbatas mendengarkan apa yang diberikan oleh guru, namun turut berperan aktif dalam kegiatan belajar seperti melaksanakan demonstrasi terkait materi yang dibahas, (2) siswa dapat memberikan contoh dari sebuah konsep abstrak yang diberikan, yaitu kemampuan siswa akan berkembang dalam mengaitkan materi yang dibahas dengan dunia nyata, (3) penerapan model ini dapat menarik perhatian siswa untuk mengikuti pelajaran, karena pembelajaran yang dilalui siswa akan dirasakan lebih menarik dan bervariasi.

Belajar dengan melakukan eksperimen membuat siswa dapat membangun konsep, prinsip, teori, dan hukum di benaknya. Melalui pengamatan atau eksperimen dapat memberikan suatu proses belajar yang berarti bagi siswa. Siswa dapat membandingkan antara teori yang diperoleh berdasarkan literatur yang mereka baca dengan kenyataan atau fakta yang mereka temukan dalam kehidupan sehari-hari. Jika antara teori dan fakta yang ditemukan tidak sesuai, maka akan terjadi konflik kognitif yang dialami oleh siswa, di sini proses belajar akan dilalui oleh siswa karena melalui proses berpikir siswa akan memperoleh pengetahuan yang lebih bermakna dan akan tersimpan dalam memori jangka panjang siswa (Öztürk et al, 2008). Hal ini disebabkan pengalaman merupakan suatu informasi yang didapatkan secara empirik (penglihatan, pendengaran, penciuman, rasa, dan perabaan) yang akan menjadi pengatahuan seseorang.

Dalam konteks sains pengalaman dapat diperoleh melalui proses melakukan sesuatu dan memikirkan sesuatu dalam lingkungannya. Pengalaman yang dimiliki pebelajar akan menjadi pengetahuan yang berupa gagasan-gagasan awal (prior knowledge). Untuk mengubah pengalaman awal (prior experience) menjadi (prior knowledge) diperlukan proses bimbingan (Mardana et al, 2006).
Dengan kegiatan seperti ini, anak akan terus mengembangkan kemampuan berpikirnya dan menggali ide-idenya dalam belajar sains layaknya seorang ilmuwan. Karena pada dasarnya tujuan utama dalam pembelajaran sains disamping untuk memahami konsep, sains juga untuk mengembangkan skill anak dalam proses keilmuwan seperti pengamatan, perbandingan, penyusunan kerangka penyimpulan, peramalan (prediksi), dan menyimpulkan (Rohandi, 2003: 119).

Permasalahan yang dikaji dalam artikel ini adalah bagaimana Peningkatan keterampilan proses sains siswa SD Inp. Unggulan BTN PEMDA Kota Makassar melalui penerepan pembelajaran Predict Observe, Disscus, Explain (PODE).

\section{METODE PENELITIAN}

Penelitian ini didesain dalam bentuk kuantitatif deskriptif guna menjelasakan dengan tepat seperti apa pelaksanaan pembelajaran model PODE di sekolah dasar. Alasan peneliti menggunakan metode kuantitatif deskriptif untuk mendapatkan gambaran mengenai implementasi pembelajaran model PODE secara mendalam, terperinci dan utuh. Dalam penelitian deskriptif ini, jenis data yang diambil adalah jenis data kuantitatif, dimana data diambil dari pengamatan langsung oleh peneliti mengenai implementasi pembelajaran model PODE di kelas.

Pendekatan yang dipilih dalam penelitian ini mencoba memadukan antara evaluative dengan tindakan (action). Uji coba lapangan dilaksanakan dengan tujuan untuk mengetahui keterterapan model PODE. Kegiatan ini di fokuskan untuk memperoleh umpan balik oleh observer yang berguna untuk perbaikan dan penyempurnaan draf pengembangan perangkat. Pelakasanaan uji coba meliputi (1) pelaksanaan pembelajaran model PODE, dan pelaksanaan posttest; (2) uji coba produk. Pelaksanaan uji coba ini, guru melaksanakan pembelajaran sesuai dengan model yang dikembangkan. Kegiatan pembelajaran berlangsung, peneliti melakukan pengamatan dan mencatat hal-hal penting selama proses pembelajaran baik aktivitas siswa maupun guru; (3) pembelajaran aktual; (4) evaluasi dan refleksi. Tahap evaluasi adalah pemberian tes formatif yaitu posttest. Adapun tahap refleksi dilaksanakan setelah kegiatan pembelajaran selesai dengan tujuan 
untuk membahas berbagai permasalahan atau kekurangan pada setiap tahap.

Penelitian difokuskan pada evaluasi proses juga difokuskan pada evaluasi hasil yang melibatkan guru dan siswa kelas V di SD Inpres Unggulan BTN. Pemda dan SD Negeri Mapala.

Analisis data dilakukan dengan statistik deskriptif dan analisis kuantitatif, statistik deskriptif diarahkan untuk menggambarkan bagaimana keterlaksanaan model PODE yang diterapkan guru. Sedangkan analisis kuantitatif untuk melihat seberapa besar hasil yang dicapai dengan menggunakan perangkat pembelajaran model PODE. Dari hasil analisis ini sehingga diharapkan dapat memberikan masukan terhadap perangkat pembelajaran yang dikembangkan, kemudian menjadi bahan revisi terhadap produk pengembangan model PODE yang disusun.

\section{HASIL \& PEMBAHASAN}

Pada bagian ini akan diuraikan hasil penelitian yang berupa; survey lapangan, dan action research. Dalam kegiatan ini sekolah yang digunakan adalah SD Inpres Unggulan BTN Pemda.

\section{Pelaksanaan Pembelajaran}

Analisis deskriptif bertujuan untuk mengetahui keterlaksanaan perangkat Model PODE dan sejauh mana tingkat perkembangan hasil belajar siswa setelah mengikuti proses pembelajaran yang terdiri atas 2 kali pertemuan. Data diolah menggunakan program Microsoft Office Excel 2007, untuk melihat hasil belajar siswa setelah menggunakan Model Predict, Observe, Discuss, dan Explain (PODE) di SD. Inpres Unggulan BTN. Pemda. Dari perhitungan analisis deskriptif diperoleh hasil pada Tabel 1 di bawah ini:

Tabel 1. Nilai rata-rata siswa

\begin{tabular}{cc}
\hline Skor & Posttest \\
\hline Jumlah siswa & 35 \\
Rata-rata & 83.04 \\
Mean & 85 \\
Standar Deviasi & 6.79 \\
\hline
\end{tabular}

Hasil belajar siswa SDI Unggulan BTN Pemda dengan jumlah 35 siswa untuk posttest rata-rata 83,04 , mean 85,00 standar deviasi 6,79. Hasil belajar SDN Mapala dengan jumlah 37 siswa untuk posttest ratarata 75,98, mean 80,00 standar deviasi 9,23. Lebih jelasnya dapat dilihat pada histogram Gambar 1

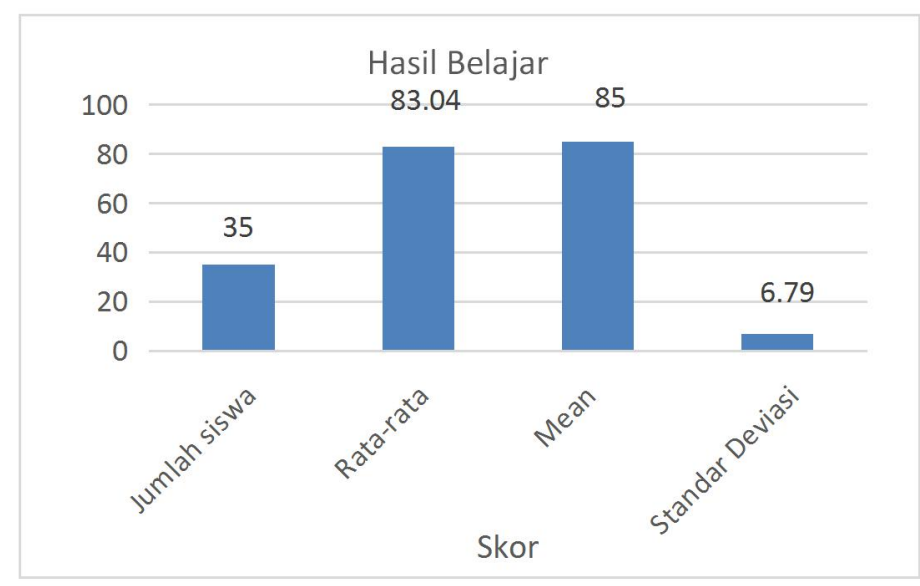

Gambar 1. Nilai Rata-rata Posttest

Berdasarkan hasil analisis data observasi pengamat tentang keterlaksanaan RPP dari 2 kali pertemuan. Rangkuman hasil pengamatan keterlaksanaan RPP dapat dilihat pada Tabel 4.8 sebagai berikut: 
Tabel 2. Hasil Pengamatan Keterlaksanaan Keterampilan Proses Sains

\begin{tabular}{ccc}
\multicolumn{3}{c}{ di SD Inp. Unggulan BTN Pemda } \\
\hline Aspek yang diamati & Rata-rata & Kategori \\
\hline Observasi/Mengamati & 3 & Baik \\
Memperediksi/Hipotesis & 2.8 & Baik \\
Melakukan percobaan & 3 & Baik \\
Menyajikan laporan & 3 & Baik \\
percobaan/Mengkomunikasi & & \\
Menarik kesimpulan & 2.5 & Cukup \\
\hline Rata-rata & 2.86 & Baik
\end{tabular}

Berdasarkan Tabel 2 menunjukkan bahwa dalam melaksanakan kegiatan observasi siswa digolongkan kategori Baik, hal itu dapat dilihat berdasarkan kemampuan siswa dalam menemukan berbagai fakta berdasarkan objek yang diamati. Kegiatan memprediksi/hipotesis digolongkan baik, terlihat pada kemampuan siswa melakukan dugaan sementara. Kegiatan percobaan yang dilakukan dikategorikan baik, dimana siswa melakukan kegiatan praktekum yang sesuai dengan LK yang telah diberikan. Untuk kegiatan menarik kesimpulan siswa dapat dikategorikan cukup

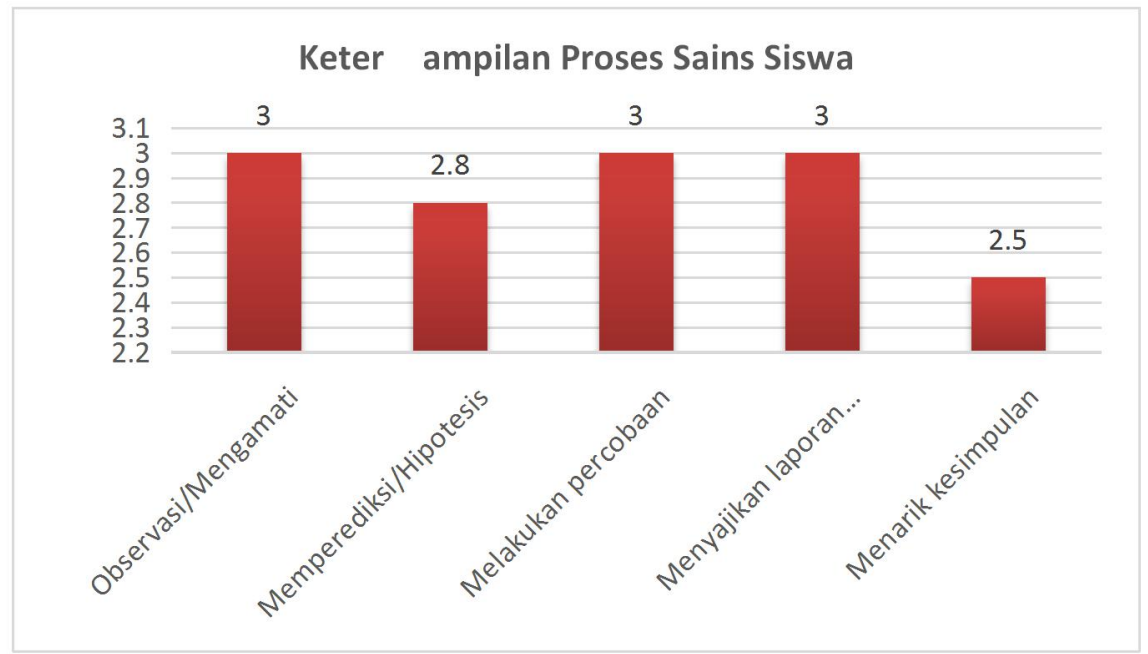

Gambar 2 Keterampilan proses sains di SDI Unggulan BTN Pemda

Berdasarkan hasil penilaian yang diperoleh melalui beberapa cara yaitu melalui observasi, analisis LKS dan tes tertulis diketahui bahwa Keterampilan Proses Sains (KPS) siswa memiliki kriteria baik. Aspek Mengamatii merupakan aspek KPS yang paling dikuasai oleh siswa dengan kriteria baik. Hal ini menunjukkan kemampuan siswa dalam menemukan fakta konsep gaya magnet dengan baik, didukung dengan metode pembelajaran yang digunakannya. Adanya kegiatan diskusi membuat siswa lebih kreatif, aktif, terampil dalam berpikir dan terampil dalam memperoleh pengetahuan, sehingga keterampilan siswa dapat diasah melalui pola berpikirnya sehingga dapat meningkatkan hasil belajar (Sagala, 2010: 74).

Hasil observasi menunjukkan bahwa siswa sudah memiliki KPS dengan kriteria baik dengan penguasaan terbaik pada aspek komunikasi. Kemampuan siswa dalam mengkomunikasikan gagasan secara lisan lebih tinggi dibandingkan bila siswa mengemukakan gagasan dalam bentuk tulisan. Hal ini disebabkan karena siswa cenderung termotivasi/antusias untuk menjawab pertanyaan yang diajukan guru. Sedangkan mengemukakan gagasan dalam bentuk tulisan dianggap membosankan sehingga berdampak pada hasil observasi yang lebih tinggi dibandingkan hasil diskusi LKS dan tes tertulis, didukung oleh pendapat yang di- kemukakan oleh Bostrom (dalam Tubbs dan Moss. 2001: 159-165), bahwa mereka yang berbicara paling banyak dalam suatu diskusi kelompok kecil akan merasa puas terhadap diskusi tersebut dan mereka yang berpartisipasi paling sedikit merasa paling tidak puas. Jelas bahwa secara 
umum, berbicara lebih menyenangkan daripada mendengarkan orang lain berbicara. Hal ini disebabkan beberapa faktor, meliputi: memperoleh pengakuan social, juga mencakup empati terhadap sudut pandang orang lain, dengan ketertarikan terhadap sesuatu yang orang lain sampaikan, mengemukakan topik yang sesuai dengan minat dan menarik perhatian orang lain.

Penilaian Keterampilan Proses Sains melalui pemberian Lembar kerja, berada pada kriteria baik, aspek melakukan prediksi sebagai aspek yang paling dikuasai dengan kriteria sangat baik hal tersebut dapat dibuktikan dengan nilai jawaban benar yang lebih tinggi dibandingkan aspek KPS lainnya yang diuji. Hal ini menunjukkan bahwa sebagian besar siswa sudah mampu memperkirakan sesuatu akan terjadi berdasarkan suatu kecenderungan atau pola yang sudah ada untuk menjawab pertanyaan, didukung oleh pemberian masalah yang dekat dengan kehidupan sehari-hari siswa. Hal tersebut sangat sesuai dengan pendapat Rustaman dkk (1992: 15) bahwa memprediksi dapat diartikan sebagai mengantisipasi atau membuat ramalan tentang segala hal yang akan terjadi di waktu mendatang berdasarkan perkiraan pada pola kecenderungan tertentu atau hubungan antara fakta, konsep dan prinsip dalam ilmu pengetahuan

Hasil analisis melalui LKS menunjukkan bahwa keterampilan interpretasi memiliki nilai paling rendah dengan kriteria sedang. Hal ini menunjukkan bahwa siswa telah mampu memaknai maksud gambar/ grafik dan membuat kesimpulan data/gambar/grafik namun masih membutuhkan bimbingan lebih lanjut oleh guru. Kurangnya pemberian soal-soal berbobot interpretasi dengan data berupa diagram atau grafik oleh guru menyebabkan siswa kurang terlatih dalam membuat kesimpulan, didukung oleh pendapat Gega (dalam Saminan, 1995: 20) yang menyarankan cara untuk mem- bantu seseorang agar dapat meng- interpretasi dengan baik, salah satu- nya yaitu dengan membiarkan mereka melatih diri menarik kesimpulan hanya berdasarkan petunjukpetunjuk atau bukti-bukti yang tidak langsung.

Aspek klasifikasi yang dinilai dengan melihat hasil kerja pada LKS menunjukkan tingkat berada pada kategori baik. Hal ini berarti kemampuan melakukan klasifikasi/menggolongkan tergolong baik sehingga siswa mampu menggolongkan data yang disajikan berdasarkan struktur dan kemampuannya, hal tersebut didukung oleh teori yang dikemukakan oleh Dimyati dan Moedjiono (2009:17), bahwa mengklasifikasikan merupakan keterampilan proses untuk memilah berbagai objek dan berdasarkan sifat-sifat khususnya, sehingga didapatkan golongan/ kelompok sejenis dari objek yang dimaksud.

Kemampuan komunikasi melalui penyajian laporan dengan menyertakan grafik untuk menyajikan informasi dan mengomunikasikan data dalam bentuk gambar termasuk kategori baik. Hal ini berarti siswa sudah memanfaatkan gambar dan informasi yang terdapat pada grafik untuk menjawab pertanyaan dengan baik hal ini didukung oleh pendapat Dewi (dalam Rohaeni, 2013: 22) bahwa kemampuan komunikasi merupakan salah satu bentuk KPS yang ber- kaitan dengan kemampuan siswa dalam menyampaikan atau menerima gagasan, ide baik secara lisan maupun tulisan, menggambarkan dan menyajikan hasil pengamatan secara visual dalam bentuk gambar, dan grafik, tidak hanya dilakukan dengan komunikasi verbal, namun juga dapat menggunakan peta konsep, bagan, grafik, gambar, simbol-simbol dan diagram. Kemampuan memprediksi dengan cara memperkirakan sesuatu yang belum terjadi berdasarkan suatu kecenderungan atau pola yang sudah ada untuk menjawab pertanyaan sudah baik, yaitu dengan mengaitkan kebiasaan dan kemungkinan yang akan terjadi dengan mengacu pada pengetahuannya terdahulu.

Kemampuan mengomunikasikan data dengan menyajikan grafik oleh siswa terkategori baik, hasil tersebut ditunjukkan oleh hasil tes tertulis untuk soal yang berhubungan dengan kemampuan komunikasi dengan kriteria baik. Hal ini sekaligus menunjukkan pemahaman siswa mengenai suatu data berada pada kategori baik sehingga siswa dapat mengubah bentuk suatu data yang diajukan dengan tidak meng ubah maknanya seperti yang di- kemukakan oleh Dewi (dalam Rohaeni, 2013: 22) bahwa komunikasi yang nyata adalah komunikasi yang efektif, tepat, praktis dan tidak bermakna ganda.

Kemampuan mengklasifikasikan data, berdasarkan hasil tes tertulis berada pada kriteria sedang. Hal ini menunjukkan bahwa pe- mahaman siswa tentang struktur dan fungsi tulang baik sehingga siswa mampu menggolongkan tulang dengan benar. Hal ini didukung pula oleh materi yang diajarkan, yaitu mengenai sistem gerak manusia, 
sehingga siswa dapat mengeksplorasi langsung anggota sistem geraknya dalam menemukan jawaban dari pertanyaan yang diajukan.

\section{KESIMPULAN \& SARAN}

Berdasarkan hasil analisis data dan pembahasan, maka dapat disimpulkan bahwa Keterampilan Proses saisn siswa Kelas V dapat ditingkatkan melalui penerapan Model PODE. Keterampilan Proses Sains siswa diikategori baik, yaitu sebesar 2,82 Untuk kepentingan penelitian, maka penulis menyarankan untuk peneliti sebaiknya menyiapkan instrumen dan analisis instrumen dengan aspek KPS yang lebih beragam agar hasil yang diperoleh lebih baik, perlu adanya bimbingan guru yang lebih intensif kepada siswa dalam proses diskusi agar siswa tidak mengalami kesulitan dalam memahami suatu konsep untuk menyelesaikan masalah dalam mengoptimalkan KPS siswa pada kegiatan pembelajaran, siswa perlu latihan-latihan agar dapat menyelesaikan soalsoal berbobot KPS dan sekolah perlu upaya meningkatkan mutu dan kualitas pembelajaran dengan menyediakan sarana dan prasarana yang menunjang kegiatan pembelajaran berbasis KPS

\section{DAFTAR PUSTAKA}

Bundu, Patta. 2002. Pengaruh Evaluasi Formatif dan Gaya Kognitif terhadap Hasil Belajar IPA Siswa Sekolah Dasar. Disertasi, UNJ (tidak diterbitkan)

Collette, A.T., \& Chiappetta, E. L. (1994). Science instruction in the middle andsecondary schools (3rd ed.). New York: Macmillan Publishing Company

Depdiknas. (2006). Peraturan Menteri Pendidikan Nasional Nomor 22, Tahun 2006, tentang Standar Isi

Dimyati dan Mudjiono. 2009. Belajar dan Pembelajaran. Jakarta: Rineka Cipta.

Gunter, M.A., Estes, T.H. \& Schwab, J.H. (1990). Instruction: A model approach.Massachusetts: Allyn and Bacon.

Irfan, Muhammad \& Syamsuardi (2017). Predict, Observe, Discuss, Explain (PODE) Meningkatkan Keterampilan Proses Sains Siswa. Makassar: Penerbit Syahadah.

Keeratichamroen, W. 2007. Using the PredictObserve-Explain (POE) to Promote students' learning of tapioca bomb And chemical reactions Tersedia pada http://www.il.mahidol.ac.th/english_site /research/

proceeding/ICASE_Wasana $\% 20$

Keeratichamroen.pdf.

Khathanvy, H. \& Yuenyong, C. (2009). The Grade Student's Mental Model Of Force And Motion Through Predict-ObserveExplain (POE) Strategy. Thailand: Khon Kaen University.

Nana Syaodih Sukmadinata. (2007). Metode penelitian pendidikan. Bandung: PT Remaja Rosdakarya

Mardana, I. B., Sukarta, N., \& Sukandar, I N. 2006. Pemberdayaan Prior Experience dalam Pembelajaran Modul Praktikum Sains dengan Model Experiential Learning sebagai Upaya Meningkatkan Kompetensi Sains Siswa SMPN 2 Singaraja. Laporan Penelitian -(Tidak diterbitkan). Undiksha Singaraja.

Öztürk, M., Emin Duru, M., Ali Özler, M., \& Harmandar. 2008. The Effect of ThinkExplain-Apply Teaching Method on the Success of Learning-Teaching: A Laboratory Study. International Journal of Environmental \& Science Education. 2(4). Tersedia pada http://www.ijese.com/.

Rohaeni, M.A. 2013. Penerapan Peer Assessment Pada Model Pembelajaran Jigsaw Untuk Menilai Kemampuan Berkomunikasi Lisan Siswa SMP Materi Pencemaran Lingkungan. Skripsi. Bandung: UPI

Rohandi, R. 2003. Memberdayakan Anak melalui Pendidikan Sains. In Pendidikan Sains yang Humanistis. Edited by P.J. Suwarno,dkk. Yogyakarta: Kanisius. Hlm112-124.

Rustaman, N Y. 1995. Pengembangan Butir Soal Keterampilan Proses Jurusan Pendidikan Biologi FPMIPA. Bandung: IKIP Bandung. tidak diterbitkan.

Saminan. 1995. Kemampuan Memahami Grafik dalam Fisika. Tesis. Bandung: Pascasarjana FPMIPA IKIP Bandung. Tidak Diterbitkan.

Student Citizen Act of 2001. Character Education: Information Handbook \& Guide. North Carolina: www.ncpublicshool.org

Tubbs, L dan S. Moss . 2001. Human Communication Prinsip- prinsip Dasar. Bandung: PT Remaja Rosdakarya. 